\title{
Participatory Planning and Quality Service Delivery in Local Authorities in Kenya
}

\author{
Emmanuel Sikuku Wanjala ${ }^{1, *}$, Zipporah Karimi Muiruri \\ ${ }^{1}$ Moi University, Department of Accounting \& Finance, Eldoret, Kenya \\ ${ }^{2}$ Jomo Kenyatta University of Agriculture \& Technology, Department of Commerce \& Economics Studies, Nairobi, Kenya
}

Email address:

emmanuelsikuku77@gmail.com (E. S. Wanjala),zippy.karimi@gmail.com (Z. K. Muiruri)

${ }^{*}$ Corresponding author

\section{To cite this article:}

Emmanuel Sikuku Wanjala, Zipporah Karimi Muiruri. Participatory Planning and Quality Service Delivery in Local Authorities in Kenya. Science Journal of Business and Management. Vol. 4, No. 5, 2016, pp. 156-164. doi: 10.11648/j.sjbm.20160405.13

Received: August 25, 2016; Accepted: September 1, 2016; Published: September 21, 2016

\begin{abstract}
The preparation of Local Authority Service Delivery Action Plans (LASDAP) through a participatory process is one of the conditions for local authorities to access Local Authority Transfer Fund (LATF) money. The process provides opportunities for promoting community involvement in the planning and budgeting process. Many development agencies such as governments, international development organizations, donors and many others have over time realized the importance of involving the communities in the development processes. The objectives of this study were to establish how community participation in planning process has affected the provision of quality water; improved healthcare facilities; education facilities; and improved infrastructure in Webuye Municipality in Kenya. The study adopted a case study research design targeting a population of 926 . A sample size of 238 was used through three sampling techniques namely: stratified, simple random and purposive. Data was analyzed both quantitatively and qualitatively. Statistical package for social studies (SPSS) helped to produce frequency tables, testing of significance and the simple regression. The data was presented in form tables, charts, graphs and figures. Overall the study findings revealed that participatory planning plays a crucial role in service delivery in local authority projects. The statistical test carried out revealed that for every unit increase in participation in project planning explain $2.3 \%$ improvement in service delivery in the projects. The t-test statistic indicated that the regression coefficients were significant at $\alpha=0.05$ level of significance.
\end{abstract}

Keywords: Participatory Planning, Quality, Service Delivery

\section{Introduction}

Participation has been defined by Heisler and Hucks [1] as a process which allows stakeholders to exert some influence over their work and the conditions under which they work. It is also defined by Wagner [2] as a process in which influence on decision making is shared between hierarchical superiors and their subordinates. According to Hyman and Mason [3], these two definitions encompass a broad range of activities through which stakeholders can affect decision making, from consultative or communication mechanisms where individual workers' input is asked for and considered by managers who retain responsibility for the final decision to participation mechanisms involving representative structures where workers are major parties to these decisions.

According to World Bank [4], it is possible to assess and approach service delivery through an accountability model for service delivery that includes three groups of stakeholders namely: citizens as clients influencing policy makers, policy makers influencing service providers which in turn deliver services to the citizens who are also clients of the services. Participatory planning process involves notices, list of attendance, agenda of the meeting, minutes of the previous meetings which all constitute measurement components of participation. LASDAP is a participatory process involving various stakeholders within a local authority. Those who participate in the process should be residents within the jurisdiction of the respective local authority. These should include self-help groups, business organizations, and resident 
associations including informal settlements, religious groups, health institutions, professional organizations, NonGovernmental Organizations and individual residents [5].

\section{Statement of the Problem}

The spread of the democratic value to virtually every society today has raised the need to examine the implications of this trend to other spheres of life. Improvement in service delivery has been implemented through various forms of community participation. These include: direct service provision by communities, contracting by communities to service providers, and new mechanisms for holding public and non-state providers accountable for services [6]. Community participation processes include an identification of stakeholders, establishing systems that allow for engagement with stakeholders by public officials, and development of a wide range of participatory mechanisms [7]. Stakeholders are individuals who belong to various identified communities whose lives are affected by specific policies and programs, and/or those who have basic rights as citizens to express their views on public issues and actions. The proponents of participatory approaches highlight the value of engagement with stakeholders in terms of greater local ownership of public actions or development projects as well as the potential [8].

There is a concern by the public in Kenya regarding the management approaches of various development projects and at the heart of the discontent is the issue of the voice and role of the beneficiaries [5]. The report further explains how mismanagement is viewed by many as a product of noninclusion since wider participation encourages transparency and accountability. Success rate of development projects remains low as a result of poor stakeholder participation in planning of projects which culminates into low community ownership of the initiatives and an enabling environment for development.

A lot of research has been carried out in regards to stakeholders' involvement and performance but little literature exists on participatory planning in local authorities and its impact on service delivery in Kenya. It is thus on this background that the study sought to unravel the effects of participatory planning on local authorities service delivery and specifically LASDAP in Webuye municipality in Kenya in an effort to add to the existing literature bank.

The study focused on four specific objectives. These are provision of clean water, health care, education facilities and infrastructure. Participatory planning was the independent variable in the study. The rationale of the study was anchored on the need to raise the productivity level of workers service delivery through appropriate motivational techniques. The involvement of workers in management decision making is considered as a means for inducing motivation in the workers leading to positive work attitude and high productivity. The study findings will be of benefit to local authorities, interested publics and other government institutions in pursuit to improve their stakeholders' public participation mechanisms. This will help bring the government closer to the people hence build more trust, transparency and accountability in service delivery.

\section{Literature Review}

\subsection{The Concept of Participation}

Participation is a process through which stakeholder's influence and share control over priority setting, policymaking, resource allocations, and access to public goods and services. The World Bank [4] defines participation as a process through which stakeholders influence and share control over development initiatives, and the decisions and resources which affect them. According to Adnan et al [9] it is a function of information through which people can come to share a development vision, make choices, and manage activities. These statements illustrate the range of definition of peoples' participation ranging from a function of information to decision-making and powers. Participation is, however, not always effective. It can be passive, co-operative and as well as ditched if it is not properly understood and nurtured. One may thus come across many types of participation as indicated below.

Table 1. The Types of Participation.

\begin{tabular}{ll}
\hline Typology & Components of each Type \\
\hline Passive participation & $\begin{array}{l}\text { People participate by being told what is going to happen or has already happened. It is a unilateral announcement by an } \\
\text { administration or project management without listening to people's responses. The information shared belongs only to external } \\
\text { professions. }\end{array}$ \\
$\begin{array}{l}\text { Participation in } \\
\text { information giving }\end{array}$ & $\begin{array}{l}\text { People participate by giving answers to questions posed by extractive researchers and project manager using questionnaire surveys } \\
\text { neither shared nor checked for accuracy. }\end{array}$ \\
Participation by & $\begin{array}{l}\text { People participate by being consulted, and external agents listen to views. These external agents define problems and solutions, and } \\
\text { may modify these in the light of people's responses. Such a consultative process does not concede any share in decision-making and } \\
\text { professional are under no obligation to take on board people's views. }\end{array}$ \\
Participation for & $\begin{array}{l}\text { People participate by providing resources; for example, labour, in return for food, cash, or other material incentives. Much in situ } \\
\text { research falls in this category: rural people provide land but are not involved in the experimentation or the process of learning. This } \\
\text { is commonly called participation, yet people have no stake in prolonging activities when incentives end. } \\
\text { People participate by forming groups to meet pre-determined objectives related to the project, which can involve the development } \\
\text { or promotion of externally-initiated social organization. Such involvement does not tend to occur at the early stages of project } \\
\text { cycles or planning, rather, only after major discussions have been made. These institutions tend to be dependent on external } \\
\text { structures, but may become independent in time. }\end{array}$ \\
\hline $\begin{array}{l}\text { Functional } \\
\text { participation }\end{array}$ &
\end{tabular}




\begin{tabular}{ll}
\hline Typology & Components of each Type \\
\hline $\begin{array}{l}\text { Interactive } \\
\text { participation }\end{array}$ & $\begin{array}{l}\text { People participate in joint analysis, which leads to action plans and the formation of new local groups or the strengthening of } \\
\text { existing ones. It tends to involve interdisciplinary methods that seek multiple perspectives and make use of systematic and } \\
\text { structured learning processes. These groups take control over local decisions, so that people have a stake in maintaining structures } \\
\text { or practices. }\end{array}$ \\
$\begin{array}{l}\text { Self-mobilization/ } \\
\text { active participation }\end{array}$ & $\begin{array}{l}\text { People participate by taking initiatives independent of external institutions to change systems. Such self-initiated mobilization and } \\
\text { collective action may or may not challenge existing distributions or wealth and power. }\end{array}$ \\
\hline
\end{tabular}

Source: Twyman [9]

\subsection{Community Participation and Service Delivery}

Community participation processes include an identification of stakeholders, establishing systems that allow for engagement with stakeholders by public officials, and development of a wide range of participatory mechanisms. Stakeholders are individuals who belong to various identified 'communities' and whose lives are affected by specific policies and programs, and/or those who have basic rights as citizens to express their views on public issues and actions. The proponents of participatory approaches, Chambers [11]; Cornwall and Pratt [12] highlight the value of engagement with stakeholders in terms of greater local ownership of public actions or development projects, as well as the potential.

Each local context reflects the dynamics between various groups that help determine how inclusive and exclusive, conflictive or cooperative, community relation tend to be. For example, research in Indonesia by Das [13] found that the relative trust that communities in Eastern Java had in local government, and the relative lack of local conflict between communities and different identity groups meant less interest in participation. In other parts of Indonesia, however, the differences of identity and in-migration led to mistrust and conflict dynamics that high lightened after the 1997 financial crisis [13].

Aspects of improving technical efficiency; allocative efficiency; and mechanisms of accountability, community participation initiatives are related to technical efficiency through areas such as overcoming information asymmetry, providing communities with information on quality through various forms of Monitoring and Evaluation ensuring that resources are spent for necessary technical resources by service providers [14]. Improving various dimensions of allocative efficiency includes greater attention to the priorities of communities, increased transparency on budgets and public resources through such mechanisms as public budgeting and public Expenditures Tracking systems, and a subsequent reduction on rent seeking by those in positions of power [4].

Mobilization of community members to identify problems and plan and manage projects helps strengthen local capacity for collective action. Community-based approaches typically aim to build social capital but while this is a useful concept it is often applied uncritically with inadequate understanding of cultural and political context and vested interests in the status quo [15].

Community participation is increasingly often endorsed as a means of strengthening state-community synergies. This can be seen in the decentralization cases from Rwanda and
Kerala, as well as the local participation law in Bolivia [16]. Emerging demand-driven approaches theoretically empower communities to command services and provide a mechanism for re-building trust and accountability and re-establishing the social contract between communities and government. Pressure to meet short term sectorial output often distracts attention from institutional reforms necessary to make service delivery systems sustainable in the longer term. Ilan [17] argues that there are various ways in which community participation processes and mechanisms can strengthen accountability and also affect service delivery outcomes. Citizens can exert their collective voice which occurs in the relationships between citizens and policy makers to influence policy, strategies and expenditure priorities at different levels of policy making according to their wishes and preferences.

Strengthening the citizen's voice accountability of policy makers motivating them to be responsive to the needs of communities and stimulates demand motivating them to be responsive to the needs of communities and stimulates demand for better public services from service providers. Local communities can be empowered by law to recall their leaders, which motivate elected leaders to be more responsive to the needs of their communities [4].

\subsection{Employee Participation}

Managers who told Human relation theory of planning participation belief simply in involvement for the sake of involvement, arguing that as long as subordinates feel that they are participating and are consulted, their ego needs will be satisfied and they will be more cooperative [18]. Job satisfaction and employee commitment receive considerable attention from industrial and organizational psychologists, management scientists, and sociologists.

Employee Participation is generally defined as a process in which influence it shares among individuals who are otherwise hierarchically unequal [9, 2]. Participatory planning management practice balances the involvement of managers and their subordinates in information processing, decision making and problem solving endeavors [2].

Coch and French [20] are considered to be the pioneers in studying employee participation in the workplace. They developed the productivity and efficiency rationale, assuming that there is a direct link between employees' involvement in decision-making and work outcomes such as the increase of job satisfaction and service productivity. Participation in decision-making can satisfy employees self-actualization needs and, by doing so, increase employees motivation and job performance. These early theoretical contributions on 
participation were not taken seriously until the mid-1980s when major works such as Lawler [21] started to emerge and make some significant impact on both academic and business circles.

Another line of enquiry on participatory management is focused on its impact on organizational outcomes such as organization performance and work outcomes, including job satisfaction, productivity, product quality, absenteeism, employee and superior relations [22]. The author argues that the best way to improve productivity is by striving for the shared goals of employees/shareholders and managers. By allowing worker input into developing the mission statement, stabling policies and procedures, determining perks, you can improve communication and increase morale and satisfaction. In line with the research on Employee/shareholder Participation has been emphasized in relation to job satisfaction [23]. In past studies showed that employee participation is positively related to performance, satisfaction, and service productivity of an employee [24; $2 ; \& 25]$.

\subsection{Employees/Shareholders Participatory Planning}

Worker/shareholder participation has been explained as a plank of industrial democracy [26]. Mills [27] described the spread of industrial democracy to Western Europe in the 1970 s a story of capitalism in transition. In his words, in countries where it is occurring, industrial democracy affects the nature, control and even ownership of private enterprise; the nature control, power and bargaining areas of the labour unions and the roles and contributions and rights of the individual worker in contemporary and future industrial society [1].

The description above shows that industrial democracy affects many aspects of lives of different people in modern society. This reason may explain the wide clamour for the introduction of worker participation arrangement in most countries. Mills [27] identified four basic forces underlying the clamour for industrial democracy. The first one was political in nature, pushed primarily by socialist and moderate labour and political leaders. The second was an industrial or economic force championed by innovative and socially-oriented management and at times, by unions. The third was an intellectual and theoretical force pushed by McGregor and Maslow [28, 29]. The last force is what Mills [27] called the revolution of rising entitlements prominent in Western Capitalist and democratic societies. This egalitarian spirit manifested itself in growing public distaste, desire and disillusionment with traditional institutions and their leadership, growing aberrant social behaviours including crime and drug abuse and new demand for participative right of every kind including women's rights.

The industrial democracy movement can be seen therefore as part of the Quality of Work Life Movement (QWLM) which spread throughout Europe during early 1970s. A major impetus to this movement was provided by the Workers Constitution Act Passed by the German Bundestag in 1972. The Act imposed a mandatory Worker Council on every German enterprise employing more than five employees. In the 1990s, the industrial democracy movement took the form of what Freeman and Rogers [30] called employee representation. Like worker participation and other stands of industrial democracy, employees' representation connotes greater influence of workers in several aspects of the work. It also involves restructuring management to meet the new demands of efficient management, international competition, rapid technological change and changing work force expectation of work [30]. A related concept to employee Participation is joint Governance. The concept was developed by Cutcher-Gershanfied [31] who defined it as an ongoing formal process where workers and their immediate supervisors or union and management bear joint responsibility for making decisions which may be narrow for instance, involving single issues.

\subsection{Kenya's Policy Approaches to Community Participation in Planning}

Sessional Paper No. 1 of 1986 whose theme was 'Economic Management for renewed Growth' placed heavy emphasis on the government's commitment to drawing on the best of the African traditions. This included participatory approach to development. In this sessional paper, specific proposals were made to increase the extent of participants' support especially for services provided by local authorities [32]. In the Development plan 1985-1990 whose theme was Participation for Progress, the importance of participatory process in the realization of the set goals for the plan period is further underscored. The Development Plan notes on harambee contribution takes the form of cash, labour, materials and lately professional services, come from various sources. There is a broad participation among citizens with support coming from the government, local authorities, administration official, elected leaders, firms, individuals, foreign agencies and NGOs. The main challenge is the construction of structures capable of shifting the centre of decision making from top to bottom so that communities are not called upon to facilitate implementation of programs and projects planned for them outside without due consideration of their felt needs and priorities. The District focus for rural development (DFRD) strategy which was launched in 1980 aimed at addressing this problem in rural areas [32].

\subsection{Benefits of Participating in Community Development Projects Planning}

Participation leads to empowerment and also results from empowerment. Power here is understood in general terms as the ability for one to make others act accordingly to his or her wishes or to work for him or her thus meeting his/her specific interests. In this context, power has to do with influencing others' behavior to meet one's own needs, requirements or standards [33].

Kaplan [34] says empowerment would entail the process of building up people's specific and collective interests and aspirations. It will imply building up people's capacity to take active responsibility over their own decisions and the 
consequences of those decisions. It is the process of enabling people to assume the responsibility to shape their own destiny.

Participation on the other hand, is a process of devolving power to the powerless [33]. The promotion to popular participation is therefore concerned with the distribution of power in the society, for it is power which enables groups to determine which needs and whose needs will be met through the distribution of resources.

Empowerment has also been understood as essentially a political process that seeks to redistribute power in favor of the poor and the disadvantaged. It involves the relinquishing of power from personalized and/or institutionalized monopoly into the hands of the ordinary people. It is a process whereby the marginalized groups in the community take the initiative for full responsibility over their own lives as subjects of their own history. The process is marked by an effort by the grass root to develop new knowledge and skills, which serve people's specific needs. This will include the appropriation and adaptation of technology in extension services so that it serves the people in response to their development priorities in the context of the people's specific cultural setting and experiences [35].

\subsection{Local Authorities' Management in Kenya}

Since 1996 the Ministry of Local Government has been instituting in the management of Local Authorities. The Kenya Government Reform Programme (KGRP) was created to coordinate the implementation of these reforms. The objective of the reforms was to improve efficiency and accountability in the operations of local authorities. Over time, the government has established rules, regulations and laws to support the reform outputs. This includes the LATF Act [36], Single Business Permits regulations, Budget preparation and LASDAP guidelines. The LASDAP objective is focused on engaging communities in identifying their needs and priorities at the local level.

The primary purpose of the LATF is to enable authorities to improve and extend service delivery to citizens. To assist in this, all local authorities are required to develop a LASDAP setting out the authorities priorities for improving local services preparation of a LASDAP is a one of the five criteria of the LATF performance component contained in legal notice 142 dated $10^{\text {th }}$ September 1999 legal notice 83 dated $24^{\text {th }}$ May 2001 and gazette notice 3505 dated $25^{\text {th }}$ May 2001 gazette notice no 2539 dated $19^{\text {th }}$ April 2002 and gazette notice no. 2533 dates $14^{\text {th }}$ April 2003 and revised guidelines of May 2009 [5].

\subsection{Conceptual Framework}

In line with the objectives of this study, the conceptual framework is based on independent variable constructs comprising quality water provision, improved health, education and infrastructure. The dependent variable here is quality service delivery.

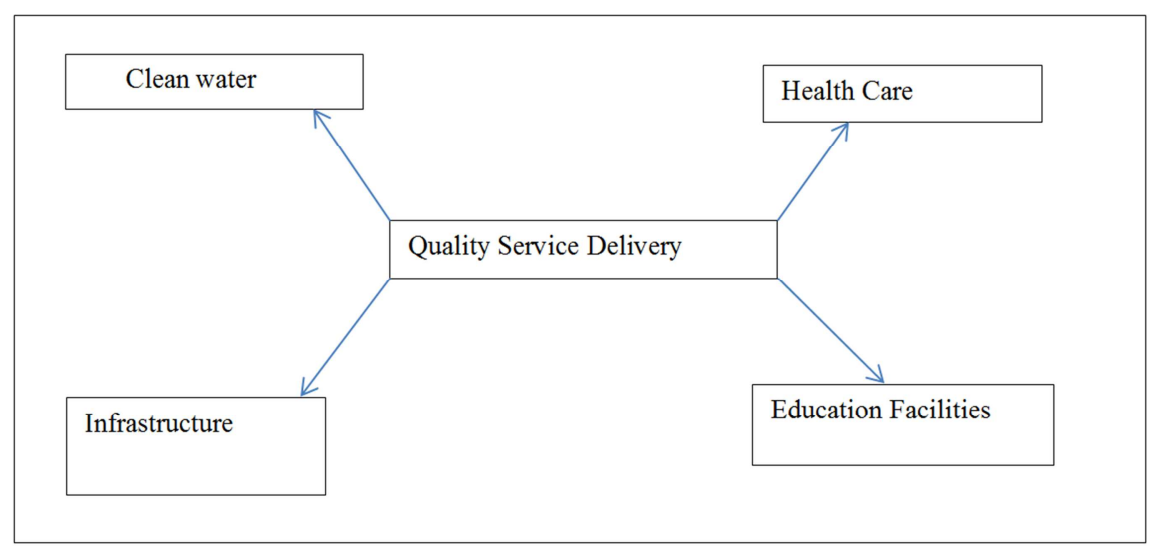

Figure 1. Conceptual framework relating participatory planning and quality service delivery.

\section{Methodology}

This study employed survey research design method. The research was conducted through cross-sectional samples that were obtained from the target population. It was both qualitative and quantitative. This method was therefore suitable as non-experimental and was concerned mainly with explanation, descriptions and explorations of opinions, attitudes, preferences and perception. This study was exploratory case study in nature which sought to examine the possible association and linkage between independent variables and dependent variables in the study. Survey method enabled the study to collect data within a short period of time and at minimum cost. The population of study included council staff, supervisory staff, other departmental heads of the district, politicians, beneficiaries of the projects and the community who participated in project identification. The researcher ensured a high degree of correspondence between a sampling frame and the sample population as the accuracy of the sample depends, first and foremost, on the sampling frame. Mugenda and Mugenda [37] argues that the sample size depends on what one wants to know, the purpose of the inquiry, what is at stake, what is useful, what has credibility and what can be done with available time and resource. The study adopted stratified, simple random and purposive sampling techniques due to the heterogeneity nature of the population. The sample size comprised $23 \%$ of 
the total population under study.

Table 2. Sample Size of the Study.

\begin{tabular}{llll}
\hline & Target Population & Sample Size & Representation \\
\hline Council staff & 88 & 20 & All officers in LASDAP projects \\
$\begin{array}{l}\text { Politicians (LASDAP Chairman, Councilors, village elders) } \\
\begin{array}{l}\text { Administrative Officers (DC, Dos and Divisional officers and other } \\
\text { government agents. }\end{array}\end{array}$ & 18 & 18 & 3 from each ward \\
$\begin{array}{l}\text { Members/Beneficiaries Community members around the LASDAP projects } \\
\text { who participated in identification of projects. }\end{array}$ & 20 & 20 & 30 from each ward \\
TOTAL & 900 & 180 & 238 \\
\hline
\end{tabular}

Source: Research Data

The study employed stratified sampling to divide staff into four departments namely: Clerk's, Treasure's, Engineering \& Planning, Social Services and Housing. The area to be covered had six administrative wards namely: Chesamisi, Matulo, Mangeni, Nabuyote, Muraka and Lwandeti wards. Simple random sampling was applied to select the respondents from each ward.

The council employees were stratified into three namely management staff, supervisors, and operational staff. The respondents from each group were picked by use of purposive sampling technique. Purposive sampling was applied to ensure the inclusion of the county clerk, who is the executive officer, the treasure who is the chief finance officer, all head of departments, the chief accountant, internal auditor, cashier, accountant in charge of payments in the sample as key informants.

The instrument that was used to collect data was the questionnaire. The questionnaires were structured with both closed and open ended questions. There was one set of questionnaire to be answered by all stakeholders. The researcher personally administered the questionnaires by method of drop and pick. To supplement the primary information, secondary data was used. The main source of secondary facts was council financial reports, council performance reports, and council minutes.

Kerlinger [38] defines validity of an instrument or scale as the success of the scale in measuring what it sets out to measure so that differences in the characteristic under study. Validity is the degree to which results obtained from the analysis of data actually represents the phenomenon under study [37]. Validity therefore, has to do with how accurately the data obtained in the study represents the variables of the study. If such data is a true reflection of the variables, then inferences based on such data will be accurate and meaningful. Validity of the research instruments was verified by the researcher through discussion of the items in the instruments with supervisors and fellow students.

Mugenda and Mugenda [37] define reliability of an instrument as a measure of the degree to which a research instrument yields consistent results or data after repeated trials. Kothari [39] observes that the reliability of the questionnaires test refers to the ability of that test to consistently yield the same results when repeated measurements are taken of the same individual under the same conditions. According to the study reliability therefore implies the extent to which consistent results can be achieved through the use of the same instruments with the same respondents at different intervals. To establish reliability, the questionnaire was tested by administering total of ten to respondents of different wards twice with the second time being a month after the first to the same respondents. This aimed at determining whether there is consistency with their responses. Quantitative data was tabulated and analyzed using simple frequencies and percentages generated using SPSS (Scientific Package for Social scientists). The data was collected and coded appropriately. It was then entered into SPSS for generating the statistics to be analyzed. Descriptive statistics mainly frequencies, percentages and cross tabulations were generated. T-test and regression analysis was carried out to find the level of significance between variables.

\section{Results}

Descriptive analysis and inferential statistics were used to analyze the data. In the descriptive statistics, relative frequencies were used in some questions and in inferential statistics.

\subsection{Demographic Data}

Out of the 173 respondents, $57.8 \%$ comprised male while $35.8 \%$ were female with a non-response of $6.4 \% .7 .5 \%$ were 25 years and below, $19.1 \%$ were between $26-35$ years, $48 \%$ were in the age bracket of $36-45$ years and $12.1 \%$ above 46 years with a non-response of $13.3 \% .8 .7 \%$ were unemployed, $17.3 \%$ self-employed, $29.5 \%$ were in formal employment, $62.4 \%$ comprised farmers and $18.5 \%$ casual workers.

\subsection{Descriptive Analysis}

The findings in the table below provide a summary of descriptive analysis of observations that were made. The likert scale questionnaire had 5 items in all the variables with 1 being the lowest and 5 the highest. The mean was used as a measure of central tendency.

Table 3. Summary of the Findings.

\begin{tabular}{llll}
\hline Element & No. of items & Mean & Interpretation \\
\hline Provision of clean water & 15 & 2.8519 & Low \\
Provision of health care & 15 & 3.8748 & High \\
Education facilities & 15 & 3.8456 & High \\
Infrastructure & 15 & 3.2097 & Moderate \\
\hline
\end{tabular}




\subsection{Inferential Statistics}

Table 4. Relationship between participatory planning and service delivery.

\begin{tabular}{lllll}
\hline Model & R & R Square & Adjusted R Square & Std. Error of the Estimate \\
\hline 1 & .153 & .023 & .017 & 1.6746 \\
\hline
\end{tabular}

Table 5. Coefficients.

\begin{tabular}{|c|c|c|c|c|c|c|}
\hline & & Unstandardized Coefficients & & Standardized Coefficients & $\mathbf{t}$ & Sig. \\
\hline Model & & B & Std. Error & & & \\
\hline \multirow[t]{2}{*}{1} & (Constant) & 2.605 & .272 & & 9.590 & .000 \\
\hline & Service delivery in local authority projects & .166 & .085 & .153 & 1.965 & .051 \\
\hline
\end{tabular}

Dependent Variable: Level of participatory planning in local authority

From the significance tailed 0.051 which $\geq 0.05$ and $<$ 1.00 , it shows that there is a direct relationship between participatory planning and service delivery in local authority projects. The $\mathrm{R}=0.153$ and $\mathrm{R}^{2}=0.023$ which implies that for every unit increase in participatory planning it explains $2.3 \%$ increase in service delivery in the local authority projects.

\section{Implications for Theory and Practice}

Results inform that $55 \%$ of the respondents were involved in project planning with majority believing that there has been improvement in projects since the introduction of LASDAP. The findings further indicate that members of the community are involved through consultation whereby they give options in identifying problems faced and feedback of the ongoing projects. Generally, respondents agree that participatory planning empowers local people and ensure fair distribution of resources. Participants determine and prioritize needs requiring urgent attention at the grassroots level. $35.8 \%$ cited interference by leaders who bring in corruption in the project planning making it difficult to reach consensus on decisions expected to be delivered out of the available scarce resources. This is reported to be accompanied by individual interests resulting to selfishness from a few especially from local political leaders.

The findings further reveal benefits realized by community in participating in health related projects provided an enabling environment for cheaper facilities accompanied by realistic plans which transformed and empowered the community giving them independence. This had the highest mean of 3.8748. Provision of education facilities had the second highest mean of 3.8456. Majority of the respondents to a total of $48.5 \%$ said that participatory planning ensured equal distribution of education facilities in the local authority. It provided a platform for the local community to air their needs and problems which were well addressed. Infrastructure was third in ranking with a mean of 3.2097 which is moderate and provision of clean water fourth with a low mean of 2.8519 .

The results herein agree with Kaplan [34] who argues that empowered people entail the process of building their capacity to influence the course of action by those in authority determining public policy. The collective influence serves peoples' specific and collective interests and aspirations. The results also agree with Abraham [40] who found out that LASDAP has ushered a process towards greater institutionalization of citizens' voice in local decision making. The findings noted on corruption in this paper are also cited in research findings by oyugi and kibua [41] who reported of interference by local politicians referred to as councilors who mismanage and misappropriate funds budgeted for local development.

\section{Conclusion}

Participatory planning has provided an enabling environment for projects, coming up with realistic plans, transformed and empowered communities giving them independence. The community benefits from participating in local development projects through an empowerment process. The local people build capacity to influence the course of action by those in authority, make them active and take responsibility over their decisions and consequences. Participation devolves power and ensures equal fair distribution of resources among all. It also enables groups determine which needs will be fulfilled by use of the allocated resources hence relinquishing power from personalized and/ or institutionalized monopolies into the hands of the ordinary people. It further allows realistic development planning as beneficiaries participate actively in the improvement of their standards of living encouraging participants to own identity with resultant projects.

\section{Recommendations and Areas for Further Research}

The study recommends a wider net of participants in the future planning to incorporate as many members of the community as possible. This ensures more ideas from a divergent perspective hence more development in the local communities since more people are involved in the planning process. It would be necessary to offer more capacity building to mitigate the challenge faced on corruption especially from opinion leaders who are mostly concerned with individual interests only since fairness and equity should be core in all areas under jurisdiction. The study recommends 
further research on the impact of participatory planning on implementation of the identified projects from a longitudinal perspective studying several authorities for the purpose of comparison of views.

\section{References}

[1] Heisler, W. Y. \& Hucks, J. W. (1977). A Matter of Dignity: Inquires into the Humanization of Work, Notre Dam. London: University of Notre Dam.

[2] Wagner, A. J. (1994). Participation's Effects on Performance and Satisfaction: A Reconsideration of Research Evidence, Academy of Management Review, 19.

[3] Hyman, J. \& Mason, B. (1995). Managing Employee Involvement and Participation, Sage Publications, London.

[4] WorldBank, (2003). World Development Report 2004, Making Services Work for poor People, Oxford University Press.

[5] Ministry of Local Government (GoK, 2009). Revised Guidelines for the Preparation, Implementation \& Monitoring of LASDAP. Nairobi: Government Printer.

[6] Matthew, A. \& Anwar, S., (2003). Voice and Local Governance in the Developing World: What is done, to what effect, and why? World Bank.

[7] Victoria, B, \& Anirudhha, D. (2006). Collective Action and Community Driven Development in Rural and Urban Indonesia, Urban Studies, 43 (9).

[8] Richard, B., (2004). The Politics of Service Delivery Reform, Development and Change, 35 (1).

[9] Adnan, S. (1992). People's Participation, NGOs and the Flood Action Plan: An Independent Review, Research and Advisory Services, Dhaka.

[10] Twyman, C. (1998). Policy Frameworks and Context 1. Issues and Linkages to Poverty, Natural Resources, and Desertification, Department of Geography, University of Sheffield.

[11] Chambers, R., (2002). Participatory Workshops: A Source Book of 21 Sets of Ideas and Activities, Earthscan.

[12] Cornwall, A. \& Pratt, G. (2003). Pathways to Participating Reflections on the Participatory Rural Appraisal. London Intermediate Technology Development Group Publishers. UK.

[13] Das, A. (2006). What's Real and What's Rhetorical? Problematizing Participation and Empowerment in Decentralized Slum Upgrading in India and Indonesia. Dissertation Proposal, UCLA Department of Urban Planning.

[14] Samanta, Da Silva., (2000). Community-Based Contracting: A Review of Stakeholder Experience, World Bank.

[15] Blackburn, J. (1999). Participatory Methods and Local Governance Effectiveness in Bolivia, Paper presented at an Institute of Development Studies (IDS) workshop, "Strengthening Participation in Local Governance".

[16] MaryKay, G. \& Kremer, M., (2006). Outside Funding and the Dynamics of Participation in Community Associations, Daniel J. Evans School of Public Affairs, Working Paper 2006-10.
[17] Ilan, K. (2000). The Devil's in The Theory. A Critical Assessment of Robert Chambers' Work on Participatory Development, Third World Quarterly, 23 (1).

[18] Richie, J. B. \& Miles, R. E. (1970). Analysis of Quantity and Quality of Participation as Mediating Variables in the Participative Decision Making Process. Personnel Psychology $23(1)$.

[19] Locke, E. A. \& Schweiger, D. M. (1979). Facts and Fiction in Analyzing Research on Participative Decision Making. A Critique of Cottion, Vollratn, Frogatt, Longnick-Hall \& Jenings. Academy of Management Review 13 (1).

[20] Coch, L., French, Jr \& John, R. P. (1948). Overcoming Resistance to Change. Human Relations, 1.

[21] Lawler, E. E., Mohrman, S. A. \& Ledford, (1992). Employee Involvement and Total Quality Management. San Francisco: Jossey Bass.

[22] Cooke, W. N. (1992). Product Quality Improvement through Employee Participation: The Effects of Unionization and Joint Union, Management Administration, Industrial and Labour Relations Review, 46 (1).

[23] Norton, D. (1989). Participation's Influence on Job Satisfaction. The Importance of Job Characteristics, Review of Public Administration, 24.

[24] Pfeffer, J. (1994). Competitive Advantage Through People. Unleashing the Power of the WorkForce. Boston. Harvard Business School Press.

[25] Verma, A. (1995). Employee Involvement in the WorkPlace. In Research in personnel and human resource management, eds M. Gunderson and A. Ponak. NewHaven, CT: Jai Press.

[26] Adewumi, F. (1993). Industrial Relations Economic Development and Democracy: A Preliminary Note in E. F. Osuji (eds), Challenges Facing Industrial Relation in Nigeria in the Context of Emerging New Economic and Political Order. Department of Adult Education University of Ibadan, Ibadan. Nigeria.

[27] Mills, T. (1977). Leadership from Abroad: European Development in Industrial Democracy, in Hesler, W. D. and Hucks, J. W. (eds), A Matter of Dignity Inquires into the Humanization of Work. London. University of Notre Dam Press.

[28] McGregor, D. (1990). The Human Side of Enterprises. NewYork: Mcgraw Hill.

[29] Maslow, A. H. (1964). Motivation and Personality. NewYork: Harper and Row

[30] Freeman, R. B. \& Rogers, J. (1993). Who Speaks for us? Employee Representation in a non-union Labour Market, in B. B Kaufman and M. M Kleiner (eds), Employee Representation: Alternative and Future Directions. IRRA Series. Imaga, E. U. 1994. Industrial Democracy in the Third world: A study of Nigeria and India, New Delhi South Asian Publishers.

[31] Cutcher- GershenFeld, J. (1991). Recent Developments in U.S. Employee Involvement Initiatives: Erosion or Diffusion in D. Sockell et al. (eds), Advances in Industrial and Labour Relations. CT: JAI Press.

[32] GoK, (1986). Sessional Paper No. 1. Economic Management for Renewed Growth. Government Printer. 
[33] Chitere, \& Mutiso. (1999). Working with Rural Communities: A Participatory Action Research in Kenya, Nairobi University Press, Nairobi, Kenya.

[34] Kaplan, R. (1996). The Development Practitioners HandBook, Pluto Publishing Press, London

[35] Mulwa, F. W. (2001). Management of Community Based Organizations, Olivex Publishers, Nairobi, Kenya.

[36] LATF Act No. 8 (1998). Nairobi. Government Printer.

[37] Mugenda \& Mugenda, (2003). Research Methods, Quantitative and Qualitative Approach. Nairobi: Acts Press.

[38] Kerlinger, F, N. (1973). Foundation of Behavioral Research: New Delhi: Surjeet Publications.
[39] Kothari, C. R. (2004). Research Methodology, Methods and Techniques, Delhi, India: New Age International Publishers.

[40] Abraham, R. M. (2014). How does Citizen Participation impact Decentralized Service Delivery? Lessons from the Kenya Local Authority Service Delivery Action Plan. Potsdam University.

[41] Oyugi, L, N. \& Kibua, T. N., (2006). Planning and Budgeting at the Grassroots Level: The case of LASDAP In: Kibua, T. N. \& Mwabu, G. (eds), (2008). Decentralization and Devolution in Kenya: New Approaches. Nairobi: University of Nairobi Press. 